\title{
LAW AS AN INSTRUMENT OF MENTAL HEALTH IN THE UNITED STATES AND SOVIET RUSSTA *
}

\section{Harold J. Berman $\dagger$}

Much has been written in recent decades about "the place of psychiatry in the law," and especially about the need to incorporate into the law insights derived from psychiatric research. Far too little attention has been given, however, to the closely related question of the place of law in psychiatry and the need to incorporate into psychiatry insights derived from legal research. Law is not merely a fact of social life; it is also a body of ideas. Implicit in legal concepts, and often explicit in them as well, are theories of human personality. Moreover, both through de facto operation and through its concepts and theories, law-like psychiatry-seeks to influence human personality. In helping to maintain social order, law at the same time and by the same token helps to maintain the mental health of the individual members of society.

Those who think of the road from psychiatry to law as simply a one-way street are misled, I believe, by the sharp distinction which is often drawn between the lawyer's concern with social order and the psychiatrist's concern with individual personality. In one of the best expositions of what law may learn from psychiatry, we are told that "the focus of the law is on society primarily, and only secondarily on the individual; in psychiatry the emphasis is almost exclusively on the individual." I But the truth is that society and the individual are really two dimensions of the same thing-man. The law, at least, cannot separate the two, and psychiatry separates them at its peril.

The word "individual" is, in fact, quite misleading, for it suggests an isolated being sufficient unto himself and devoid of relationships with others. Psychiatrists are concerned, of course, not with individuals in this abstract sense but with real people, people who have mothers and fathers, husbands or wives, children, friends, teachers,

* An address given at the Second Institute on Preventive Psychiatry, State University of Iowa, April 11, 1959. Reprinted with revisions from Berman, Law as an Instrument of Mental Health in the. United States and Soviet Russia, in RECENT Contributions of Biological and Psychosoctal Investigations to Preventive Psychiatry: Proceedings of the Second Institute on Preventive Psychiatry 120 (Ojemann ed. 1959).

+ Professor of Law, Harvard University. A.B. 1938, Dartmouth College; Certificate of Graduate Studies 1939, London School of Economics and Political Science; M.A. 1942, LL.B. 1947, Yale University.

1 Guttmacher \& Weinofen, Psychiatry and the Law 4 (1952). 
fellow workers, and so forth. But it should not be forgotten that these more intimate relationships of family, neighborhood, school, church, factory, farm, office, or other face-to-face groups are part of a larger system of social relationships of city, region, country, civilization, and indeed mankind. The so-called individual is not only a father, brother, son, husband, machinist, alumnus, member of First Church, and the like; he is also a state-licensed driver of an automobile, mortgagor of his house under state and federal law, member of a national labor union, veteran, citizen, Christian, and potential victim of nuclear war. The larger communities in which he lives, and the law by which they are to a considerable extent governed, play an important part in shaping his inner life. Social order and human personality being inextricably interdependent, the law which helps to create social order helps to shape the ideas and emotions of the people living in that social order.

It is interesting in this connection to recall that the great French sociologist Emile Durkheim, in demonstrating the social causes of suicide-the fact that the rate of suicide varies among different societies according to differences in social structure and social values-used the term anomie, literally "absence of law," to denote the type of social emptiness which is conducive to emotional breakdown." One can carry this idea further if one tries to imagine a complex society such as our own existing without law. Unless some substitute were found, fears, frustrations, aggressive desires, and other emotional disturbances would be likely to become overpowering. Indeed, there is some evidence that the weakness of law in the international order-that is, the prospect of a nuclear war-sometimes gives rise to such emotional disturbances today.

In helping to give order to people's relationships with each other -not only order but order corresponding in some degree to the community's sense of justice-law performs a therapeutic function for the members of society. As the English psychiatrist Ranyard West has put it, law controls human aggressiveness, giving a peaceful outlet to the destructive dispositions which exist in all men and in all societies: "We ought to be able to regard the law as controlling for us those qualities in us which we never really master ourselves." 3

Each of the social functions of law has a corresponding psychological function for the individual members of society. Thus the punishment of a criminal, to speak of that aspect of law with which psychiatrists are perhaps most familiar, may be viewed in social terms

2 Durketim, Le Sutcine (1930); cf. Parsons, The Structure of Soctal Action 324-38 (1949). See also de Grazia, The Political Community : A Study OF ANOMTE (1948).

3 West, Conschence and Soctety: A Study of the Psychological PrerequiSITES OF LAW AND ORDER 166-67 (1942). 
as a means of expressing the community's condemnation of the criminal act (its retributive-or, perhaps better, its expressive-function), or in psychological terms as a means of appeasing the desire for vengeance felt by the offender's victims and by those who identify themselves with his victims; in social terms, as a means of discouraging people generally from committing crimes (its deterrent function), or in psychological terms as a means of instilling the moral values of the community in people's minds; in social terms, as a means of isolating the offender from the opportunity to commit new crimes at least during the period of incarceration (its preventive function), or in psychological terms as a means of strengthening the sense of personal security of people, their freedom from fear of criminal attacks; in social terms as a means of correcting the offender and helping to make him a socially useful person (its rehabilitative function), or in psychological terms as a means of encouraging him to change his emotions, attitudes, and beliefs. I do not speak now of the extent to which these various functions are justified or fulfilled, but only of the interaction of their social and psychological elements.

Underlying these social and psychological functions of criminal law is a broader function which is rarely, if ever, mentioned. That is its function of maintaining the community's sense of communityits function of giving the members of the community a sense of belonging to the community and of sharing its values. Criminal law is important to society not only because of its effects upon people who commit crimes or upon people who are deterred by it from committing crimes. It is also important because of what might be called its integrative function. Criminal law integrates us into our community and even into the larger community of mankind by teaching us all what is absolutely required of us as fellow members of society-absolutely required, in the sense that we are held responsible and punishable by society itself for a breach of the requirement. We are taught by our family, our neighborhood, our church, our school, and other intimate groups that it is wrong to steal, wrong to use violence, wrong to tell lies, wrong to evade responsibilities. When we learn that society itself-the larger community of city, state, nation, and even the international community-condemns theft, aggression, slander, tax evasion, and similar acts as publicly punishable offenses, we are brought into a relationship with that larger community and made to feel our membership in it; that feeling of membership provides an essential element of personal stability and of belonging. Thus criminal law performs a supporting and integrative function in the life of every person by reinforcing and expanding the social dimensions of his personality. 
In considering the therapeutic functions of law we should not, however, confine our attention to criminal law but rather should view criminal law in the context of the larger body of law of which it is a part. As in dealing with crimes, so in resolving conflicts between individuals or groups of individuals over personal injuries, family responsibilities, labor relations, contract and property rights, civil liberties, and hosts of other matters which give rise to dispute and require regulation, the legal process-whether judicial, administrative, or legislative-helps to maintain not only social equilibrium but also the psychological equilibrium of individual members of society. It helps, above all, to give them a sense of their relationship to the community as a whole, a sense of their participation in its values. All branches of law serve to reduce grievance tensions, to protect normal expectations, and to teach right attitudes toward each other and toward society as a whole. ${ }^{4}$ We need a traffic signal at an intersection (to use the homeliest of illustrations), with its attendant legal obligation to slow down or stop, because otherwise people coming from opposite directions might give vent to aggressive impulses toward each other-either before or after a collision; otherwise people might have no basis for calculating what the consequences of stopping or going would be; otherwise people might more readily yield to the temptation to go even though they know they ought to stop; and otherwise people might feel that the community has failed to give guidance in an area in which community guidance is needed.

I have been dealing thus far with the psychological functions of law in general. But it is apparent that whether law adequately fulfills these functions depends upon whether certain assumptions about human personality, implicit in law, are in fact valid. Every legal system presupposes certain qualities in the nature of the people who are subject to it-certain ideas, certain attitudes, certain emotions, certain capacities and incapacities. To what extent are the values that are expressed or implied in legal norms and legal procedures actually shared by the individual members of society? To what extent can they be instilled by law? To what extent does the human personality actually correspond to the image of man reflected in legal institutions?

Here we may profitably turn to a comparative study of legal systems, for different systems of law reflect different conceptions of the nature of man. A thorough study would include many widely divergent systems. One would like to compare the various conceptions of human nature reflected in primitive law, in the Canon Law of the Church, in the law of Islam, in the law of Calvin's Geneva, and in

4 For a more complete elaboration of these functions of law, see BERMAN, THE NATURE ANd Functrons of LAw 29-40 (1958). 
many other legal systems. Yet there are advantages in confining our attention to two systems, our own and that of Soviet Russia, which have enough in common to make them truly comparable and yet are sufficiently different to provide a perspective.

Let me turn first to some of the features which Soviet law shares with our own legal system and with the legal systems of continental European countries (to which it is closer by tradition and inclination). Soviet law, contrary to what many Americans would suppose, is a highly developed system with a large body of legislation, with trial and appellate courts, with codes of criminal law, civil law, labor law, and family law, with sixty to seventy thousand lawyers and a substantial amount of private litigation. Soviet citizens may own propertyhouses, cars, television sets, and the like (but not land or shops or factories), may save money, and may within limits dispose of such property and money by contract and by will. In addition, Soviet state enterprises-which conduct the bulk of the economic activities of the Soviet Union-are regulated by law and enter into contracts with each other for the purchase and sale of goods under limits imposed by the planning and administrative authorities; there is a very large amount of litigation between state enterprises in a special system of courts established to adjudicate disputes arising out of such contracts. In short, the Soviet social and economic system is regulated to a high degree by legal norms and procedures which form a complex and mature system, as contrasted with a primitive legal system such as that, for example, of the Cheyenne Indians or of the Melanesians.

Turning particularly to criminal law and procedure, we again find similarities to Western systems, both in general outline and in many details. The criminal codes make punishable not only crimes against the state but also personal and property crimes-homicide, rape, assault, theft, embezzlement, and so forth. Criminal procedure follows the continental European model: investigation of crimes is conducted by an examining magistrate who questions the suspects and witnesses preparatory to issuing an indictment; after indictment the accused is tried by a court; the burden of proof rests with the prosecution; and the accused is entitled to a defense counsel. A Soviet court is interested in the same questions which would concern an American court: did the accused commit the act with which he is charged? Did he commit it intentionally? If not intentionally, ought he to have foreseen the consequences of his act? Was he sane-the Soviet term is "imputable" ("responsible") - when he acted?

Indeed, the Soviet tests of imputability or nonimputability are not essentially different from the test of our M'Naghten rules taken 
together with the "irresistible impulse" rule which prevails in some eighteen states. Specifically, Soviet law defines nonimputability as the inability of a person "to realize the consequence of his actions or to control them, as a result of a chronic mental disease, temporary mental derangement, mental infirmity or other pathological state." 5 Thus, the intellectual factor (absence of capacity to realize) and the volitional factor (absence of capacity to control) are both essential to nonimputability. Interestingly enough, Soviet law, like ours, also suspends punishment of a person who is nonimputable at the time of sentencing and permits the imposition of punishment upon him after his recovery. ${ }^{6}$

Psychiatrists may well be shocked and disappointed to discover that the Soviet lawmakers, starting all over again in the twentieth century to make a new legal system, have adopted Aristotelian and Thomistic conceptions of reason and will and have developed a legal system which, like our own, assumes that in general people are rational and should be punished for their misdeeds. Indeed, the Soviet experience is some evidence that a belief in freedom of will and in the capacity of man, through reason, objectively to know reality, is implicit in all modern systems of law: we can hardly imagine today a law of contracts which assumes that men do not have intent and knowledge; or a law of torts which assumes that it is meaningless to say, "he ought to have known that if he didn't put on his brakes he would hit me"; or a criminal law which exonerates a defendant on the ground that his parents brought him up to hate society. Psychiatrists may complain that such conceptions rest on a false view of human nature; they may deride the notion that each of us has two little men in the top of his head, one called Reason and the other called Will. The lawyers in all countries will answer, "if there is no reason, no choice, no will, then there can be no law; we will not sacrifice the legal order to the vagaries of your science."

Yet when we take a closer look at both Soviet and American law, we find that neither system has been immune to important changes in concepts of human nature which have come about in the twentieth century and which are reflected in modern psychiatry. And in looking more closely we shall also find some of the crucial differences between Soviet and American law as well as between Soviet and American psychiatric theories and practices.

The influence of modern psychiatric concepts-especially Freudian concepts-upon the American legal system during the past forty years,

5 Fundamental Princtples of Criminal Procedure of the U.S.S.R. art. 11 (1958).

B Ibid. 
though subtle and indirect, has nevertheless been far-reaching. The influence is felt less in explicit changes in legal rules than in the interpretation and application of the rules. The law of divorce, for example, remains more or less unchanged in the books; it is based on the concept of breach of marital duty, of fault, with overtones of sin. Divorce law in practice, however, has come to be based on the concept of the incompatibility or maladjustment of two individuals. Similarly, in many areas of the law of personal injury, the concept of fault has given way to the concept of distribution of losses among those better able to bear them than the injured parties. Here the explanation is usually conceived in social and economic rather than psychological terms-the worker injured in the course of employment, even though by his own negligence, requires compensation for he is unable to protect himself out of his savings; the plaintiff struck by an automobile or by an exploding bottle is often awarded damages by the jury though the defendant was not negligent-contrary to the rules expounded in the judge's charge-on the assumption that the defendant's insurer is the better "risk-bearer." But the social-economic rationale has important psychological implications: the independent self-reliant individual who bears the risks of his own negligence and profits from his own prudence has been replaced, in much of our operative legal thinking, by the dependent, indeed virtually helpless, individual who needs protection. This is not to say that divorce on grounds of mutual incompatibility or tort liability without fault could not exist without modern psychiatric concepts; they have existed in other societies which had quite other concepts of man. But it seems likely that in our society these developments in law are connected with a breakdown of an older psychology. Personal injury law, like divorce law, is more and more seen in terms of the readjustment of an unfortunate situation rather than in terms of fault. No one needs to be blamed; the parties are simply victims of life-perhaps even of their own accident-proneness.

Many other illustrations of this subtle shift in legal psychology (though it would be wrong to suggest that it is more than a tendency) could be adduced from civil law, not to mention administrative law; its most striking expression, however, is found in criminal law. We have decided that a youth under eighteen, or under sixteen, is not subject to criminal punishment at all; he is to be judged on the basis not of what he did but of his whole personality, and treated in terms of correction rather than penalty. In some states the sex offender, and in some states the alcoholic, although sane in the traditional sense, are also exonerated from public condemnation as criminals and 
subject only to medical psychiatric treatment. Moreover, in the past few years we have seen the adoption by the District of Columbia courts of a rule hitherto in force only in New Hampshire that a person is not criminally responsible for an unlawful act which was the product of mental illness or mental defect, without reference to whether he had the capacity to control his conduct. ${ }^{7}$ These special rules for juveniles, for sexual psychopaths and alcoholics, and for the mentally ill reflect a more general tendency in modern criminal law to view the person who has committed an antisocial act as a victim of his heredity and environment rather than as a free, rational, moral agent-a tendency by no means explicit in the criminal law generally but implicit in much of its administration.

If we turn to the influence of Soviet psychological concepts upon Soviet law, we find quite a different story. In the first place, since Soviet psychology and psychiatry are required to conform to the general doctrines laid down by the Communist Party and since the law, too, is subject to the same doctrines, it is not surprising that there is no such open clash between psychiatric and legal concepts in the Soviet Union as there is in the United States. Soviet psychologists and psychiatrists are not permitted to publish ideas which the Party leadership considers harmful to the social (including the legal) order; but by the same token, Soviet law in general conforms to the concepts of human personality held by Soviet psychologists and psychiatrists. Thus a synthesis is achieved between psychiatry and lawpartly at the expense of both and partly to their mutual benefit.

Soviet theories of human personality are conceived in Pavlovian rather than in Freudian terms. ${ }^{8}$ Freud's emphasis on the role of the unconscious is rejected. "Conscious understanding" and "conscious purposive action" are considered the key to human personality. At the same time, great stress is placed upon the possibility of influencing human thought, feeling, and action by environmental changes. It is the Soviet view that man is conditioned but that through conscious effort he can rise above his conditions. Indeed, training and selftraining have been declared to be categories separate from environment and heredity in the shaping of human personality.

The concept of man expressed in Soviet psychological writings is in many respects close to the traditional Western legal concept of the free, rational, moral agent. Deterministic conceptions which were prevalent for many years have been denounced since the mid-1930's.

7 Durham v. United States, 214 F.2d 862 (D.C. Cir. 1954) ; cf. Note, Implementation and Clarification of the Durham Criterion of Criminal Irresponsibility, 58 Colum. L. REv. 1253 (1958).

8 See generally Bauer, The New Man in Soviet Psychology (1952). 
The individual is said to be responsible for his behavior-responsible, indeed, for his own character. ${ }^{9}$

On the other hand, Soviet psychological theory emphasizes that it is society which sets the conditions for the development of the individual human personality; and in the Soviet Union, at least, society does so consciously and purposely in order to achieve definite psychological objectives. The family, the school, social organizations, social institutions such as law, and, above all, the Communist Party, have the task of seeking to inculcate feelings of social responsibility, duty, courage, love of country, devotion to the Party, and a Communist Weltanschauning. ${ }^{10}$

A true story of Soviet psychologists in action may reveal more than these generalizations can about their concept of man and of the role of society in shaping his personality. Professor Henry Murray, the Harvard psychologist, reports that during recent conversations with Soviet psychologists in Moscow he was told of an experiment conducted with small children. If a three-year-old child is told that at a certain signal-the flashing of a light-he is to squeeze a certain ball once, it is apparently very difficult for him to obey. He may squeeze the ball before the light flashes or may squeeze it several times after the light flashes. However, the Soviet psychologists told Professor Murray, they were able to get the child to perform the requested act by first teaching him to say, "when the light goes on I will squeeze the ball once." By teaching him, in other words, to give himself the command, they were able to persuade him to overcome the negativism characteristic of his age-group. The next step was to teach him to form the words in his mouth without vocalizing them and then squeeze the ball. Ultimately the child was taught simply to think the words and then perform the act.

The key not only to Soviet psychology but also to Soviet law is conscious conditioning of emotions, attitudes, and beliefs. What I have spoken of as the therapeutic function of law becomes, in Soviet theory and practice, its primary function-its raison d'etre; it becomes, indeed, one of the principal determining factors not only of legislation but even of judicial decision. Soviet jurists speak of this in terms of the "educational role" of law. Thus Soviet family law is designed to teach the members of the family to accept their mutual responsibilities:

9 "A man takes part in the shaping of his own character and he himself bears a responsibility for that character." RUBINSHTEIN, OSNOVY OBSHCHEI PSIKHOLOGII 475 (1946), quoted in BAUER, op. cit. supra note 8, at 149.

10 "The early years of childhood play an essential role in the development of character. However, the Freudian notion that character is fixed in early childhood is erroneous. This error arises from the failure to understand the role of consciousness in character development. Man takes an active part in reshaping his own character to the extent that it is related to a Weltanschanung . . . RUBINSHTEIN, OSNOvY ObSHCHEI PSIRHoLOGII 475 (1946), quoted in BAUER, op. cit. supra note 8, at 150. 
since 1944 divorce has been made relatively difficult, especially where there are children to be cared for; the network of family economic responsibilities is very wide, with grandparents and grandchildren having mutual obligations of support. Similarly, Soviet tort law is designed to teach people to be careful, and even in workmen's compensation cases the element of fault enters to permit an injured worker to recover from the state business enterprise his full losses, and not merely the statutory tariff, where the injury was due to the negligence of management. And Soviet contract law is designed not only to teach respect for contracts ("contract discipline") but also to teach people, especially business managers, how to utilize contracts in the interests of the general economic plan as well as in the interests of their individual state enterprises.

To say that Soviet law has an educational, or therapeutic, function is only to say that it is like the legal systems of other countries; the difference is that in the case of Soviet law that function is not merely implicit but explicit, not merely incidental but central to the very determination of rights and duties. American contract law, too, helps to teach people what kinds of agreements to make, but that is not often thought to be an express purpose of our contract law; only occasionally are our legislatures concerned with such teaching and it does not generally have a direct bearing upon the decision of a court. The Soviet legislature, on the other hand, is concerned very much with the kinds of contracts people may make, and even when deciding a dispute over an alleged breach of contract the Soviet court will quite often be interested in the question of whether the agreement was properly drawn from the point of view of the parties' mutual interests as well as from that of society's interests. Indeed, in the sphere of economic contracts between state business enterprises there is a special "pre-contract procedure" whereby the court in effect writes the contract for the parties if they are in dispute as to what its terms should be.

The point becomes clearer, perhaps, by illustration from Soviet criminal law, where the determination of the guilt or innocence of the accused may depend upon the educational value of such a determination for him and for society. The extreme case, both in Soviet and American law, is that of the juvenile offender; under both systems, a fifteenyear-old boy who deliberately robs a store, for example, is held not to be guilty of a crime, because it is believed that to subject him to social condemnation is not good for him or for society; on the other hand, though his theft might have been a very minor one, he may be subjected to confinement in a reformatory for an indefinite period-a far more severe punishment, perhaps, than a mature man might receive 
for the same act-not because of what he did but because of what he is. The mature man, on the other hand, under our system is not supposed to be punished for what he is but only for what he did. Under the Soviet system, however, questions of motivation, of attitude, and of character enter into the very finding of criminal intent and criminal negligence. This has been true particularly in the area of crimes against the state-called, until December 1958, "counter-revolutionary crimes." It is true also in many other spheres of criminal law. Soviet writers state, and Soviet judicial decisions bear them out, that the specific intent of the accused to do the particular act-to shoot the victim-must be considered in the whole context of his beliefs, his will, and his emotions. Depending on his whole personality, his guilt may be increased or diminished. Indeed, under an express provision of the Soviet criminal code, if the actor no longer constitutes a social danger at the time of trial he may be acquitted.

Thus fault, wrong, duty, will, intent, and other moral and rational concepts of law are retained, but their function is changed: they are not only means of determining legal rights but also-and perhaps primarily-means of training people to be industrious, honest, cooperative, efficient, resourceful, responsible, and, above all, loyal citizens. Indeed, rights are conferred by the Soviet state in order to encourage such virtues, in order to develop the very kind of human personality which Soviet psychologists proclaim to be the "new Soviet man."

But there is an underlying paradox involved: if the "new Soviet man" is what he is said to be, why is so much conditioning necessary? In fact he is not yet what he is said to be. He still needs training. He is therefore treated not as a mature, independent adult but as an immature, dependent youth who must be guided and disciplined. His rights are not his by inherent right but are his as gifts of the State, given conditionally in return for his loyalty to the State. Indeed, when the State has felt itself threatened, it has withdrawn altogether the rights of many and has substituted terror as a means of training. Even where no question of politics as such is involved, individual rights are insecure insofar as they are interpreted as instruments of educating the "new Soviet man" to accept his social responsibilities.

Thus both Soviet psychiatry and Soviet law have suffered by their intermarriage. Soviet psychiatry has been almost totally cut off from research into the unconscious area of human personality. Soviet law has been deprived of security against political intervention. Both are used as instruments for the creation of a society unified by the world-view of the Communist Party. At the same time they both have derived certain benefits from their union. The emphasis in Soviet 
psychology-carried over into psychiatry-upon conscious purposive action, upon the integration of personal and social goals, and upon the creation of social conditions conducive to such an integration is not only an important supporting element in the lives of normal, or well, people, but also has certain advantages as a basis for treating some kinds of mental illness.

It is difficult to assess Soviet psychiatric practice in view of the paucity of our information about mental illness in the Soviet Union. Soviet psychiatrists have said that the incidence of "serious" mental illness is about the same, in proportion to the population, as in Western Europe and the United States, and such statistics as are available seem to support their conclusion. ${ }^{11}$ We may suppose that the enormous political and ideological pressure imposed by the Party leadership (the purges of the late 1930's which sent hundreds of thousands of people to labor camps in remote regions of Siberia on the flimsiest of charges and with secret administrative trials are an example) coupled with crowded living conditions and shortages of consumer goods have created anxieties, frustrations, fears, depression, and similar emotional disturbances among large numbers of Soviet citizens. At the same time, very little is known about the social causes of mental illness, and it may be that the psychological effects of regimentation and even of common suffering and sacrifice are by no means so debilitating to mental health as is popularly supposed. Certainly one senses in the Soviet Union today that the common suffering which the Russian people have shared during the past forty years contributes to a sense of solidarity and even of mission among large numbers of people, and at the same time that there is a widespread sharing of pride in the economic, technological, and social progress which has been made by the country as a whole.

If we turn from speculations concerning the state of mind, so to speak, of the people of the Soviet Union to what we know more surely concerning Soviet psychiatry, we find some striking differences between the system of psychiatric care in the Soviet Union and that which prevails in the United States. In the first place, although the total number of hospital beds in the two countries is about the sameapproximately $1,500,000$ - the number of psychiatric beds is not more than 13 per cent of the total in the Soviet Union, whereas it is about 50 per cent of the total in the United States. ${ }^{12}$ Secondly, the number of doctors and the ratio of doctors to psychiatric patents is far higher in the Soviet Union than in the United States. There are an estimated

${ }^{11}$ Cf. Field, Approaches to Mental Illness in Soviet Society: Some Comparisons and Conjectures, 7 Soctal Prob. 277, 278 (1960).

12 Id. at 282, table 2. Cf. Gorman, EVERy Öther Bed (1956). 
15,000 Soviet psychiatrists out of a total of 360,000 doctors, compared with about 10,000 American psychiatrists out of a total of about 200,000 doctors. (The total populations of the two countries are approximately $210,000,000$ and $175,000,000$, respectively.) In Soviet hospitals there is an average of one doctor to about 27 psychiatric patients, whereas in American public mental hospitals the ratio is one doctor to over 180 patients. ${ }^{13}$ Finally, Soviet psychiatric patients are generally treated in neuropsychiatric clinics, of which there were 2,327 in $1956,{ }^{14}$ and are, in addition, cared for through a variety of social devices: workshops and factories for psychiatric patients, psychiatric colonies where patients engage in agricultural work, rehabilitation centers, and, perhaps most important, state subsidies for families to take care of the mentally ill at home.

Leaving aside the important question of the quality of Soviet psychiatry, which I am not competent to judge, it is apparent that pervading the Soviet system of care for the mentally ill is the concept that such care is the responsibility not only of the psychiatrist but also of others. Hospitalization, which in the United States is by far the chief instrument of psychiatric care, is reserved in the Soviet Union largely for acute cases. The idea is very strong in the Soviet Union that in many instances-perhaps in most-the patient may be treated effectively by changing his environment-by moving him, for example, to other surroundings, changing his job, or putting him in a special psychiatric workshop, factory or agricultural colony, or rehabilitation center. Above all, care at home is seen as a major factor in the social treatment of mental illness-a solution which is perhaps more readily acceptable in a society like the Soviets' in which the majority of people live in agricultural communities. ${ }^{15}$

Thus the emphasis of Soviet psychiatry on social conditioning, together with the emphasis of Soviet law on inculcating moral and

13 Field, supra note 11, at 285.

14 Id. at 287.

$15 \mathrm{Dr}$. Field suggests that possibly the shortage of psychiatric beds may have stimulated the use of other methods of treatment of the mentally ill in the Soviet Union. Id. at 285-86. He adds: "It may also be remembered that it was precisely a shortage of psychiatric beds that launched one of the more exciting approaches to mental illness in the West. This is the system of emergency psychiatry or psychiatric first-aid pioneered by Dr. A. Querido in Amsterdam, Holland ... Querido believes that: '. . In the last analysis, the cure or the adaptation of the mentally disturbed can be accomplished only in society and a successful stay in society is the only real test of any therapeutic endeavor. The removal of the mentally disturbed from his background implies the sidestepping of the nucleus of the problem." "Dr. Field states: "The main contribution the Soviets have made, lies, probably, in their concepts of not condemning psychotic patients to the idle, demoralizing, de-socializing, untherapeutic and wasteful life of the chronic patient in the large mental hospital. Concomitant with this approach, is the bringing of psychiatric care into the community, even into the patient's. home if necessary, and the linking of this treatment with the general network of medical facilities maintained under a system of socialized medicine." Id. at 296. 
intellectual attitudes and ideas, combine to create a rather good social atmosphere and rather good social institutions for the treatment of the mentally ill, despite the harm which is done to psychiatry itself as a science by the arbitrary exclusion of Freudian insights.

Turning finally to the benefits which Soviet law derives from its marriage, so to speak, to Soviet psychiatry, I would like to refer briefly to the use of psychiatrists in criminal proceedings. ${ }^{16}$ The provisions of Soviet law regarding the use of psychiatrists in judicial proceedings are more satisfactory from almost any point of view than the corresponding provisions of the law in any of the states of the United States. Under Soviet law, the testimony of a qualified psychiatric expert is required both in the preliminary investigation of a crime and upon trial, if any question arises as to the psychiatric condition of the person charged. In the United States, only California and Indiana require that the court call a psychiatric expert in cases involving the defense of insanity, and only Massachusetts has a procedure for a routine psychiatric examination prior to trial of persons charged with certain offenses. Under Soviet law there is provision for a joint examination by opposing psychiatrists, and in proper cases a joint report. In the United States, there is no such provision-except under the Uniform Expert Testimony Act, which has been adopted in no state. Soviet law provides for the commitment of the accused to a hospital prior to examination in appropriate cases. Only eighteen American states have similar provisions. Under Soviet law only a qualified psychiatric expert is permitted to testify concerning the mental illness of the accused. Under American law, in all jurisdictions, such testimony may be given by any doctor. Psychiatrists' expenses and fees, under Soviet law, may be assessed to the accused if he is guilty, provided he is not indigent; if he is not guilty, or if he is guilty but indigent, they are assessed to the state treasury; moreover, a psychiatrist, whether called by the investigator, by the court, or by the accused, may not without sufficient reason refuse to appear and give his conclusions.

The use of psychiatrists in criminal cases in the Soviet Union is strongly influenced by the work of a special institute, the Serbskii Institute of Forensic Psychiatry, which is under the Ministry of Health of the U.S.S.R. American psychiatrists and lawyers might well study the work of this Institute, which has been in existence since 1922, with the thought of forming-under private auspices-an American Institute of Forensic Psychiatry, which like the Serbskii Institute would be

16 See generally Probleny Sudebnor Psikhiatris [Problems of Forensic Psychiatry] (Buneev ed. 1957) ; Sudebnala Psikhiatria [Forensic Psychiatry] (Buneev ed. 1954); Berman \& Hunt, Criminal Law and Psychiatry: The Soviet Solution, 2 StaN. L. Rev. 635 (1950). 
a scientific research institute and a means of training experts who, on request by a court, could provide psychiatric testimony before, during, or after trial. The Law-Medicine Research Institute established at Boston University in 1958 is an important first step in this direction.

As in the United States generally, Soviet forensic psychiatrists are called upon to testify not only as to the mental illness of the accused but also as to his capacity to know the nature of his acts and to control his conduct. At the same time, the Soviet court is required to consider in detail his psychiatric condition in determining the question of his nonimputability, and a conviction (or an acquittal!) may be reversed on appeal if the court has failed to state the medical as well as the legal foundations for its decision. Thus the juxtaposition of medical and legal criteria is maintained in both procedural and substantive law. This is more readily possible in Soviet Russia than here, it seems to me, because the distance between psychiatry and law is not nearly so great there as here.

It might appear to some that the analysis which I have given leads to the suggestion that we adopt Soviet methods of dealing with the problems of mental illness, especially as they come up in court proceedings. That suggestion is very far from what I am driving at. Soviet law and psychiatry are both distorted by Communist doctrines and Communist practices which are entirely unacceptable to anyone who believes in freedom; both the lawyer and the psychiatrist are subject to official pressures which we would consider intolerable. The point is rather that the study of the Soviet system enables us to understand our own system better. It shows us that our own backwardness in the development of proper procedures for the use of psychiatrists in criminal cases is due not only to the mistrust of psychiatry by the lawyers but also to the failure of the psychiatrists to face squarely the requirements of a sound legal order. We need, I submit, more effort on the part of psychiatrists to accept whatever there is of value in traditional legal concepts. We need to have more attention given by psychiatrists to the role of the conscious in mental illness and to the possibilities of treatment by environmental and social changes. We need cooperation between psychiatrists and lawyers in devising new social methods of care for the mentally ill outside of hospitals. We must at all costs avoid any solution which would inhibit the freedom and independence either of psychiatry or of law; but we surely can, through freedom, match what the Russians have done through force.

In "matching" the Soviet cooperation between law and psychiatry, we should attempt to build into our law and into our psychiatry a conception of man which is more complete and more balanced than 
the Soviet conception. Man is not uniformly the dependent and growing youth of Soviet law; nor is he uniformly the reasonably prudent man of our legal tradition; nor is he uniformly the victim of his heredity and early childhood, as much of our psychiatry assumes. The varieties of social experience call forth many diverse aspects of his personality. Depending on his situation, he may have the helplessness of a child, the youth's capacity for dedication and service, the selfconfidence and assertiveness of a young man, the prudent maturity of middle age, the wisdom of old age. A healthy legal system will give reflection and reinforcement in procedural and substantive rights and duties, at appropriate times and appropriate places, to all the various phases of man's nature. A healthy science of psychiatry can play an important part in the development of such a legal system. 